NBER WORKING PAPER SERIES

\title{
LIGHTING UP AND SLIMMING DOWN: \\ THE EFFECTS OF BODY WEIGHT AND CIGARETTE PRICES ON ADOLESCENT SMOKING INITIATION
}

\author{
John Cawley \\ Sara Markowitz \\ John Tauras \\ Working Paper 9561 \\ http://www.nber.org/papers/w9561 \\ NATIONAL BUREAU OF ECONOMIC RESEARCH \\ 1050 Massachusetts Avenue \\ Cambridge, MA 02138 \\ March 2003
}

The authors thank JeffDeSimone, Michael Grossman, Judy Shinogle, and conference participants for helpful comments and suggestions. The authors gratefully acknowledge funding from the Robert Wood Johnson Foundation. The views expressed herein are those of the authors and not necessarily those of the National Bureau of Economic Research.

C2003 by John Cawley, Sara Markowitz, and John Tauras. All rights reserved. Short sections of text not to exceed two paragraphs, may be quoted without explicit permission provided that full credit including Cnotice, is given to the source. 
Lighting Up and Slimming Down: The Effects of Body Weight and Cigarette Prices on Adolescent Smoking Initiation

John Cawley, Sara Markowitz, and John Tauras

NBER Working Paper No. 9561

March 2003

JEL No. I0

\begin{abstract}
$\underline{\text { ABSTRACT }}$
This paper examines the influence of body weight, body image, and cigarette prices in determining adolescent smoking initiation. Adolescents who desire to lose weight may initiate smoking as a method of appetite control. Such behavior may undermine the goals of tobacco control policies that seek to prevent smoking initiation. Using a nationally representative panel of adolescents, we show that smoking initiation is more likely among females who are overweight, who report trying to lose weight, or who describe themselves as overweight. In contrast, neither objective nor subjective measures of weight predict smoking initiation by males. Higher cigarette prices decrease the probability of smoking initiation among males but have no impact on female smoking initiation. These gender-specific differences may help explain the mixed and inconclusive evidence of the impact of price on smoking initiation found in previous literature.
\end{abstract}

John Cawley

134 MVR Hall

Department of Policy Analysis and Management

Cornell University

Ithaca, NY 14853

and NBER

jhc38@cornell.edu

John Tauras

Department of Economics

University of Illinois at Chicago

601 S. Morgan Street, Room 2129

Chicago, IL 60607

and NBER

tauras@uic.edu
Sara Markowitz

Rutgers University, Newark

and NBER

365 Fifth Ave, Floor

New York, NY 10016

smarkow@newark.rutgers.edu 


\section{INTRODUCTION}

Smoking and obesity are the two leading causes of preventable deaths in the United States. It is estimated that over 400,000 deaths per year are attributable to smoking (CDC 1993), and 280,000 to 350,000 deaths per year are attributable to obesity (Allison et al. 1999). In December 2001, Surgeon General Dr. David Satcher warned that obesity may soon overtake tobacco as the chief cause of preventable death (Associated Press 2001).

Body weight and smoking status are closely interrelated. There is a broad literature showing that adult smokers weigh less than non-smokers (Nemery et al. 1983; Fehily et al. 1984; USDHHS 1988; Klesges et al. 1989). Furthermore, research on the effect of smoking cessation on weight consistently shows that smoking cessation by adults results in an average weight gain of 2-3 kilograms (Gordon et al. 1975; USDHHS 1990; Klesges et al. 1989; Pinkowish 1999).

The vast majority of smokers begin smoking during adolescence (USDHHS 1994). This may also be the stage of life when people, especially girls, are most sensitive to their body weight. The perception that smoking controls weight is common among youths, especially among teenage girls (Camp et al. 1993, Brooks 1998). As a result, teenagers who want to lose weight may begin to smoke based on the belief that smoking will facilitate weight loss.

From a policy perspective, it is important to know the role of body weight and body image in determining smoking initiation. Previous research has shown that tobacco control policies, such as higher taxes on cigarettes, can deter smoking. However, as the prevalence of obesity increases among children and the dangers associated with being overweight become well-known, smoking rates may rise if personal goals of weight loss overshadow the deterrent effects of anti-smoking public policies.

This paper examines the dual roles of body weight and tobacco control policies in 
predicting smoking initiation by adolescents. In particular, the impact of perceived body weight, actual body weight, cigarette prices, and socioeconomic factors on smoking initiation are examined for males and females. The results indicate that females who report trying to lose weight and those who describe themselves as overweight are more likely to initiate smoking. In contrast, neither objective nor subjective measures of weight predict smoking initiation for males. Higher cigarette prices deter smoking initiation by males, but have no impact on smoking by females.

\section{RELEVANT LITERATURE}

A few previous studies have examined the effects of a demonstrated concern about weight on smoking status in youths. Tomeo et al. (1999), Wiseman et al. (1998), and French et al. (1994) find that concern about weight is correlated with current smoking or smoking initiation for female adolescents. Voorhees et al. (2002) show that girls are more likely to be daily smokers at ages 18-19 if they tried to lose weight when younger or are currently trying to lose weight. Tucker (1983) is the only study to look at effect of actually being overweight (as opposed to perceptions of overweight or desire to lose weight) as a predictor of smoking initiation and finds that obese boys have stronger intentions of smoking than lighter boys. Girls are not examined.

Most of the existing studies on smoking and weight suffer from the fact that their samples are drawn from restrictive geographic areas or use samples otherwise not representative of the population of American teenagers. Moreover, French et al. (1994) is the only study to examining the probability of transition from non-smoker to smoker in a panel of respondents. Our study adds to this literature by examining the transition from non-smoker to smoker in a large, 
nationally representative sample of youth, and by focusing on both weight concerns and actual body weight.

Another drawback to the existing research is that these studies all fail to include tobacco control policies, such as cigarette prices or taxes, which are potentially important predictors of smoking initiation. The omission of these economic variables will not bias the coefficient on weight concerns unless the two are correlated; however, we believe that controlling for both is important because it yields information on the relative importance of the two factors in the smoking initiation decision.

Economic studies of smoking behaviors have focused on the impact of price and other regulatory variables, while ignoring the role of body weight. To date, only five econometric studies have attempted to examine the impact of cigarette prices or taxes on smoking initiation, the results of which vary considerably. In the earliest studies, Douglas and Hariharan (1994) and Douglas (1998) find that cigarette prices are uncorrelated with the decision to initiate smoking. However, the results of these first studies should be interpreted with caution given that duration analysis is applied to cross sectional data and retrospective information on smoking initiation. Incorrect recall by participants on smoking initiation, along with errors from matching price with past residence will influence the results. As Douglas (1998) notes, the panel data requirements needed to use duration modeling are not met. In another study using retrospective data, Forster and Jones (1999) find that higher taxes will prolong the amount of time before an eventual smoker actually begins, although the magnitude of the impact is small.

The results from initiation studies that use longitudinal data are mixed. Tauras et al. (2001) conclude that cigarette prices are strongly negatively correlated with the probability of transition to daily smoking. However, the effect of price on the probability of transition to 
smoking any quantity of cigarettes is not statistically significant. DeCicca et al. (2002) find cigarette taxes and youth smoking initiation to be inversely related in some model specifications. However, when they control for state fixed effects, the effect of cigarette excise taxes is not statistically significant. None of these studies analyze the smoking decision separately by gender. As we will show, there are large and important differences in the determinants of smoking initiation for males and females. Weight concerns influence the initiation decisions of females while the price of cigarettes plays a much stronger role for males.

\section{METHODS}

\section{Analytical Framework}

This section develops a model of smoking initiation using standard economic models developed by Becker (1965) and Grossman (1972). The utility function for adolescents is a function of smoking $(\mathrm{S})$, health $(\mathrm{H})$, and other goods $(\mathrm{X})$, all of which are subject to tastes $(\mathrm{u})$ : 1) $U=f(S, H(S, W(E, S, G)), X ; u)$.

A production function for health is embedded in equation 1, in which smoking and excessive weight are each negative inputs into the production of good health. Weight also has a production function and can be lowered by dieting or exercise (E) and smoking. Weight is also partly determined by genetics $(\mathrm{G})$.

The budget constraint faced by adolescents is represented by equation 2 where total earned and unearned income (I), is equated to the sum of EPe, expenditures on weight loss (e.g. dieting and exercise); expenditures on smoking (SPs); and expenditures on all other goods (XPx):

2) $\mathrm{I}=\mathrm{EPe}+\mathrm{SPs}+\mathrm{XPx}$. 
Maximizing utility subject to the budget constraint yields the following first order condition for smoking:

3) $U_{S}+U_{H} H_{W} W_{S}=\lambda P s-U_{H} H_{S}$,

where subscripts denote marginal effects. This first order condition shows that the benefits of smoking, which include the direct effect of smoking on utility $\left(U_{S}\right)$ plus the health benefits of losing weight $\left(\mathrm{U}_{\mathrm{H}} \mathrm{H}_{\mathrm{W}} \mathrm{W}_{\mathrm{S}}\right)$, equals the utility forgone because money was spent on smoking $(\lambda \mathrm{Ps})$ and the utility loss from the health consequences of smoking $\left(\mathrm{U}_{\mathrm{H}} \mathrm{H}_{\mathrm{S}}\right)$. In any time period, if the benefits to smoking outweigh the costs, the individual will initiate or continue smoking. If the costs outweigh the benefits, the individual will abstain from smoking.

The first order condition for smoking implies the following quasi-structural equation that will serve as the basis for empirical estimation:

4) $S=f(P s, W, I, u)$, where $\mathrm{S}=1$ if the respondent is a current smoker and $\mathrm{S}=0$ otherwise. Smoking status is determined by the full price of smoking, body weight, income, and tastes. The quasi-structural equation is estimated instead of a reduced form demand equation since we are interested in the impact that weight concerns have on the decision to smoke. The model predicts that an increase in the price of cigarettes will decrease the probability of being a smoker, but an increase in the weight loss effects of smoking $\left(\mathrm{W}_{\mathrm{S}}\right)$ will increase the probability of smoking. This latter effect might be offset by the negative effects of smoking on health $\left(\mathrm{H}_{\mathrm{S}}\right)$.

This framework and the empirical estimation thereof can be used to help measure the effectiveness of tobacco control policies. For example, assume that every teen has the same belief about the detrimental health effects of smoking $\left(\mathrm{U}_{\mathrm{H}} \mathrm{H}_{\mathrm{S}}\right.$ is the same for everyone), and that smoking provides the same utility $\left(\mathrm{U}_{\mathrm{S}}\right)$ for everyone. Further assume that smoking causes the 
same amount of weight loss for every individual ( $\mathrm{W}_{\mathrm{S}}$ is the same for everyone). Each individual will then compare the price of smoking $(\lambda \mathrm{Ps})$ to the utility benefits of weight loss $\left(\mathrm{U}_{\mathrm{H}} \mathrm{H}_{\mathrm{W}}\right)$. For individuals who place a low value on weight loss, changes in the price of cigarettes will more heavily influence smoking status because the benefits of smoking will be less. For people who place a high value on weight loss, price changes may have less impact. Existing literature provides some clues as to which may be more important for certain groups. For example, girls tend to be much more sensitive to their weight and are more likely to try radical weight loss strategies (Tomeo et al. 1999; Camp et al. 1993). This would imply that tax increases on cigarettes may be less effective for girls than for boys.

\section{Empirical Estimation}

The empirical model is derived from the structural equation above:

5) $\mathrm{S}_{\mathrm{T}}=\alpha_{1} \mathrm{Ps}_{\mathrm{T}}+\alpha_{2} \mathrm{~W}_{\mathrm{T}-1}+\alpha_{3} \mathrm{I}_{\mathrm{T}}+\alpha_{4} \mathrm{u}_{\mathrm{T}}$.

In each period, if the benefits derived from smoking outweigh the costs, the adolescent will smoke (either initiate or continue). The determinants of that decision include the full price of smoking (Ps), weight (W), income (I), and other observed and unobserved social and interpersonal factors that enter the decision to smoke (u). Equation 5 is estimated separately by gender. The measures of weight are lagged to the previous time period to ensure that weight is measured before the anorectic effects of smoking begin. Additional potential sources of endogeneity of the weight measures are discussed further below.

Equation 5 is estimated using a discrete time duration method, which is an appropriate statistical technique for examining the structural determinants of the decision to make a transition from one state to another. The discrete time methodology uses a probit specification to 
estimate the hazard rate (Allison, 1984). In the current period, individuals who are not at risk of making a transition (current smokers) are removed from the sample, and a binary dependent variable is created which equals one if a transition is made from non-smoker to smoker in the subsequent wave. Smokers who quit and then relapse are not included in the analysis since these respondents are removed from the sample after the first transition.

\section{DATA}

The data come from the National Longitudinal Survey of Youth 1997 Cohort (NLSY97). The NLSY97 is a nationally representative sample of 9,022 youths aged 12-16 as of Dec. 31 1996. The first wave was conducted in 1997, with follow-ups currently available for 1998, 1999 and 2000. Thus, the age range of this panel (ages 12-21) covers the ages at which the vast majority of eventual smokers initiate.

Two measures of smoking initiation are constructed. The first represents the transition from non-smoker to smoking any positive quantity of cigarettes; this is termed "less stringent initiation". The second, "more stringent initiation", reflects the transition from non-smoker to a frequent smoker, as measured by having smoked at least 15 days in the past 30 . Light smokers (those smoking less than 15 days but more than zero) are omitted from this measure. These transitions are examined three times_-between 1997 and 1998, between 1998 and 1999, and between 1999 and 2000. For example, in 1998, a respondent is considered an initiator if in 1997 the respondent had never smoked a cigarette but a positive quantity was reported in 1998 . This process results in up to three observations for each individual. Respondents reporting smoking in 1997 are omitted from the estimation sample.

Table 1 shows that 10.3 percent of the males and 8.5 percent of females initiate smoking 
of any level at some point during the sample period. About 4 percent of males and 2.5 percent of females initiate heavy smoking during the sample period.

The questions regarding weight that were asked of NLSY97 respondents include objective and subjective measures: weight in pounds and height in inches, the respondent's description of his or her weight, and a question asking what the respondent is currently doing about his or her weight. These questions are asked in every interview, thus, the weight variables are known prior to smoking initiation for most respondents.

Weight and height are used to calculate a body mass index (BMI), which is then classified into weight categories as defined by the Centers for Disease Control. Children are classified as normal weight if their BMI lies between historic $5^{\text {th }}$ and $85^{\text {th }}$ percentiles as calculated by the CDC. Children are classified as at risk of being overweight if their BMI is greater than the $85^{\text {th }}$ percentile and are considered overweight if their BMI is greater than the $95^{\text {th }}$ percentile; to reiterate, these percentiles are as defined by the CDC using historic data and are not the percentiles of the NLSY 1997 sample. The values of BMI in each percentile vary by gender and age. For example, a 16-year-old girl with a BMI greater than 28.8 is considered overweight, while a boy of the same age is considered overweight when the BMI exceeds 27.5. Seventeen-year-olds must have a BMI greater than 29.6 and 28.2, for girls and boys respectively, to be considered overweight.

One objective measure and two subjective measures of weight are used in the analysis. The objective measure is a dichotomous indicator that equals one if the respondent's BMI exceeds the $85^{\text {th }}$ percentile, which includes respondents who are overweight or at risk of being overweight. Table 1 shows that 32 percent of males and approximately 25 percent of females fall into this category. The first subjective measure is a dichotomous indicator for whether or not the 
respondent is trying to lose weight. Twenty-five percent of males and 45 percent of females report trying to lose weight in this sample. The second subjective measure is a pair of indicator variables created from a question of how the respondent describes his or her weight.

Respondents' self-perceived weight is categorized as overweight if they describe themselves as very overweight or overweight ( 21 percent of males and 32 percent of females). Those describing themselves as very underweight or slightly underweight are categorized as underweight (18 percent of males and 12 percent of females). The omitted reference group consists of respondents who reported being "about the right weight".

The characteristics of the youth and family included as regressors are: age, race, gender, education level (enrolled in high school, high school drop-out, high school diploma or in college), marital status (single versus married, separated, or divorced), youth income (which includes earned income and allowances from parents), household size, family structure (child lives with both parents, child lives with no parents, child lives with a step parent or one parent), an indicator that equals one if the child does not identify with a religion, and work status. Table 1 shows means and standard deviations for these variables.

The price of cigarettes is included in all models and comes from the Tobacco Institute's annual Tax Burden on Tobacco. The state price is a weighted average of a pack of 20 cigarettes based on the prices of single packs, cartons, and vending machine sales where the weights are the national proportions of each type of sale. These prices are inclusive of state level sales taxes applied to cigarettes. Cigarette prices are merged in based on the state of residence or the location of the respondent's college, when applicable.

To partially control for unobserved state sentiment towards smoking that may affect cigarette prices and smoking initiation, all models include a dichotomous indicator for whether 
or not the respondent resided in a tobacco producing state when the surveys were conducted. This indicator takes on a value of 1 if the individual resides in Kentucky, North Carolina, Georgia, South Carolina, Tennessee, or Virginia, and zero otherwise.

\section{ESTIMATION AND RESULTS}

Estimates from the duration analysis are presented in Tables 2-4. Table 2 contains results for models that include the indicator for BMI greater than the $85^{\text {th }}$ percentile. Table 3 contains results for models that include an indicator for attempting to lose weight. Table 4 contains results for models that include indicator variables for self-perceived overweight and underweight.

The first three models of Tables 2-4 employ the less stringent measure of initiation, which represents the transition from nonsmoking to smoking any positive quantity of cigarettes. Model 1 contains estimates for both genders combined. Models 2 and 3 contain estimates for males and females, respectively. Models 4, 5, and 6 of Tables 2-4 are identical to models 1,2, and 3, except that they employ the more stringent initiation measure (transition from nonsmoking to smoking on at least 15 of the past 30 days).

Given the panel nature of the data, the standard errors of the estimates are cluster corrected at the individual level using a robust method of calculating the variance covariance matrix developed by Huber (1967). The cluster correction relaxes the assumption of independence of observations so that observations only have to be independent across individuals but not among observations of the same individual. 


\section{Unobserved Smoking Sentiment}

It is possible that unobserved state sentiment toward smoking may affect both youth smoking initiation and cigarette prices (through the enactment of cigarette excise taxes). To control for this possibility several strategies were pursued. First, state fixed effects were included in the models. Unfortunately, the inclusion of state fixed effects in conjunction with the time fixed effects eliminated virtually all the independent variation in cigarette prices. An ordinary least squares regression of cigarette prices regressed on state and time effects alone yielded a coefficient of determination of 0.99 . These results implied that there is not enough variation in cigarette prices within states to include state fixed effects in the model.

Second, the smoking initiation equations were estimated on a subsample of the respondents who did not reside in tobacco producing states during the time that the survey was being conducted. That is, individuals who resided in Kentucky, North Carolina, Georgia, South Carolina, Tennessee, or Virginia when the surveys were conducted were eliminated from the regressions. The results from this specification are very similar to those presented in the paper. No significant differences with respect to cigarette prices or body weight are observed. Results are available upon request.

Finally, the models presented in this paper are conducted on the full sample of respondents and include a dichotomous indicator for whether or not the respondent resided in one of the tobacco producing states. In general, the results suggest that, all else equal, individuals who reside in tobacco producing states are more likely to initiate smoking; these coefficients, however, fail to reach the 5 percent significance levels in all models. 


\section{Results for Price of Cigarettes}

The real price of cigarettes has a negative and statistically significant impact on smoking initiation among males in all the models that were estimated for both measures of smoking initiation. However, cigarette prices are found to be insignificant determinants of female smoking initiation. Given this, this section will focus on the impact of price on smoking initiation decisions of males.

Since the probit model is nonlinear in nature, the estimated parameters do not directly provide meaningful information for understanding the exact relationship between cigarette prices and smoking initiation. Predicted probabilities and elasticities provide a more substantively meaningful method of interpreting the results. Table 5 provides the predicted probabilities of male smoking initiation when cigarette price is set at its minimum, maximum, and mean values holding all other independent variables at their mean. Table 5 also provides the estimated price elasticities of smoking initiation holding all independent variables, including price, at their mean.

The models estimated in Table 2 imply that varying the real price of cigarettes (base years of price deflation $=1982-1984)$ from its minimum of $\$ 1.12$ per pack to its maximum of $\$ 2.57$ per pack decreases the predicted probability of less stringent male smoking initiation from 0.126 to 0.067 , a decrease of 5.9 percentage points. Similarly, the models estimated in Table 2 imply that varying the real price of cigarettes from its minimum to its maximum value decreases the predicted probability of more stringent male smoking initiation from 0.055 to 0.016 , a decrease of 3.9 percentage points. The predicted probabilities of male smoking initiation derived from the models estimated in Tables 3 and 4 are virtually identical to those estimated in Table 2 .

The average price elasticities of less stringent smoking initiation and more stringent smoking initiation across all models estimated on males in Tables 2-4 are -0.93 and -1.59 , 
respectively. These results indicate that a 10\% increase in cigarette prices will decrease less stringent smoking initiation by approximately $9.3 \%$ and decrease more stringent smoking initiation by $15.9 \%$. These finding clearly indicate that increases in cigarette prices will prevent many young males from initiating cigarette smoking.

\section{Results for Overweight}

We find that both objective and subjective measures of weight have important impacts on the smoking initiation decisions of female adolescents. However, we find no significant impact of any weight measure on smoking initiation by males. Therefore, this section focuses solely on the impact of body weight on the smoking initiation decisions of females.

Table 2 shows that females whose BMI the previous year was greater than the $85^{\text {th }}$ percentile were significantly more likely to initiate smoking. In addition, Table 3 shows that females who are attempting to lose weight are also significantly more likely to initiate smoking. Table 4 shows that females who perceive themselves as being overweight are more likely to initiate smoking than are females who perceive themselves as being of normal weight. However, the perception of being overweight is not significant at conventional levels when the more stringent measure of initiation is employed.

Table 6 provides the predicted probabilities of female smoking initiation holding all other independent variables at their mean values. Since all the weight measures are discrete, the minimum predicted probability corresponds to the predicted probability that the dichotomous indicator takes on a value of zero, whereas, the maximum predicted probability corresponds to the dichotomous indicator taking on a value of one. 
The models estimated in Table 2 imply that females who have a BMI at or above the $85^{\text {th }}$ percentile have a 0.016 greater probability of less stringent smoking initiation and a 0.007 greater probability of more stringent smoking initiation. While small in magnitude, these numbers represent large percent increases in the probability of smoking initiation; specifically, a 21.1 percent increase in the probability of less stringent initiation, and a 43.8 percent increase in probability of more stringent initiation.

With respect to the subjective measures of body weight, females who are trying to lose weight have a 0.025 (36.2 percent) greater probability of less stringent smoking initiation and a 0.007 (50 percent) greater probability of more stringent smoking initiation. Finally, females who perceive themselves as overweight have a 0.024 (33.3 percent) greater probability of less stringent smoking initiation and a 0.005 (33.3 percent) greater probability of more stringent smoking initiation.

\section{ENDOGENEITY}

In the empirical estimation of equation 5 , it is important to consider two potential sources of endogeneity that may bias our results. First, there may exist a positive association between weight concerns and smoking for reasons other than weight loss. This might occur if there exist unobserved factors that affect both weight and smoking. For example, adolescents suffering from depression may both overeat and smoke to lift their spirits. Adolescents who place little value on the future may assign little importance to the future health consequences of both smoking and obesity. Second, reverse causality may bias the results; that is, in addition to body weight affecting smoking decisions, smoking decisions may affect body weight. This second source of endogeneity is likely to be small or non-existent due to the use of lagged measures of 
weight on the right-hand side of equation 5, which is estimated only for those who were nonsmokers at the time weight was recorded.

Two methods are used to test and potentially correct for the possible endogeneity of body weight and weight perceptions due to unobserved third factors. The first is the method of instrumental variables (IV), which identifies the causal effect using variables that are strongly correlated with objective weight and uncorrelated with the error term in the smoking equation. IV is used when the measure of weight is objective. In the first stage of IV estimation, the indicator for female $\mathrm{BMI} \geq 85^{\text {th }}$ percentile is predicted using an indicator of obesity for the respondent's biological mother (defined as BMI greater than or equal to 30) observed at one point in time. Our identifying assumption has two parts. The first is that mother's obesity status is highly correlated with the respondent's obesity status through genetics. This is supported by research in behavioral genetics, which finds that genes explain roughly half of the variance in weight across people (Allison et al., 1996), and that children are expected to share half of their genes with their biological mothers. Due to shared genes, there is a strong correlation between the weights of mothers and children. Most estimates from U.S. data of the correlation between the adult BMI of a mother, and the childhood or adolescent BMI of her child are in the range 0.21-0.36 and the correlation does not differ by the gender of the child (Maes et al. 1997). The second part of the identifying assumption is that mother's obesity status is uncorrelated with the residual in the smoking equation.

Table 7 compares estimates from linear probability (LP) regressions to those of a two stage least squares regression in which overweight status is instrumented for using mother's obesity status. ${ }^{1}$ The positive and highly significant t-statistic (which is greater than 15 ) on

\footnotetext{
${ }^{1}$ Heckman and MaCurdy (1985) and Angrist (2001) show the validity of using linear probability models for estimating simultaneous equations with dichotomous endogenous variables.
} 
mother's obesity status in the first stage of two-stage least squares indicates that it is a powerful instrument for a teenager's weight status. However, the Durbin-Wu-Hausman chi-square test (Durbin, 1954; Wu, 1973; Hausman, 1978) indicates that we cannot reject the null hypothesis that the LP coefficient is consistent and asymptotically efficient. Thus, there is little evidence to suggest that this measure of weight is endogenous in the female smoking initiation equations. Similarly, there is no evidence that weight is endogenous for the sample of males, however, both the LP and two stage estimates are not statistically significant (results are not shown, but are available upon request).

The second approach to address the endogeneity issue is to control for other factors that have the potential to affect both smoking and weight. This approach is most useful for the models using weight perceptions, for which no valid instruments are available. We add to the set of regressors a measure of depression and a measure of behavioral problems, both of which were elicited in the first wave of the NLSY97 from a subsample of respondents who were born in 1982, 1983, and 1984. The responses to these two questions were assigned to all waves of each individual's data. Regarding depression, these youth were asked how well the statement, "you are unhappy, sad, or depressed" described them over the past six months. Possible answers are: not true, somewhat or sometimes true, or often true. A behavioral and emotional problems scale was also calculated for each of these respondents based on a series of questions regarding attitudes about self; higher scores indicate more behavior problems. The drawbacks to the inclusion of these questions are: first, we are forced to limit our sample to the subset of NLSY97 respondents who were asked these questions; and second, these measures were only taken at a single point in time and therefore cannot measure the effect of changes in attitudes or behaviors over time. 
Table 8 compares estimates from models for females that include measures of depression or behavioral problems to models that exclude these determinants that were estimated using the same sample. The estimates from Table 8 suggest that females who suffer from depression and exhibit behavioral problems are more likely to start smoking than are individuals who are not afflicted with these problems. However, only the coefficients on behavioral problems are significant at the 5 percent levels in all models, while the coefficients on depression are only significant at the 10 percent level in the model using the less stringent measure of smoking initiation. More importantly, the inclusion of these measures does not alter the finding that weight concerns are correlated with smoking initiation. While the magnitudes of the weight coefficients fall slightly, there are no noteworthy differences between the models that include the measures of depression/behavioral problems and those that exclude these determinants. In the corresponding models for the sample of males (available upon request), the subjective measures of weight remain statistically insignificant across all models.

\section{SUMMARY}

This paper examines the influence of body weight, body image, and cigarette prices on the smoking initiation decision of adolescents. Discrete time duration models are estimated using data from the National Longitudinal Survey of Youth, 1997 Cohort, for two definitions of smoking initiation: one representing the transition from non-smoker to smoking any quantity, and the second representing the transition from non-smoker to frequent smoker.

We present a model of smoking initiation in which an individual weighs the full costs and benefits of smoking. The costs include the detrimental effects of smoking on health and the monetary price of purchasing cigarettes, while the benefits include any weight loss resulting 
from smoking and the direct pleasure derived from smoking. For females who place a high value on the benefits of weight loss, price considerations may play only a minor role in the initiation decision. For males who tend not to value weight loss as strongly as females, the monetary price may have greater influence on the decision to smoke.

We find that females who have a high body mass index, who report that they are trying to lose weight, and who describe themselves as overweight are more likely to initiate smoking than other females. Cigarette prices have an insignificant impact on female smoking initiation. In contrast, we find that cigarette price is a strong determinant of initiation for males, while neither actual body weight nor measures of perceived body image predict their smoking initiation.

Results from the previous literature on cigarette prices and smoking initiation have been mixed and inconclusive. In contrast, we find consistently strong price effects for males, and insignificant effects for females. For males, the estimated price elasticity is -0.9 for initiation into any quantity and is -1.6 for initiation into frequent smoking. When calculated using a pooled sample of males and females, these elasticities fall to -0.4 and -0.6 , respectively, and the estimates are often not statistically different from zero. Such elasticities calculated for a pooled sample paint a misleading picture of the impact of price since they represent a weighted average of the diverse gender-specific effects. As a result, caution should be exercised when drawing conclusions from the previous literature that has not considered gender differences in the decision to smoke. 


\section{REFERENCES}

Allison DB, Kaprio J, Korkeila M, Koskenvuo M, Neale MC, and Hayakawa K. "The Heritability of Body Mass Index Among an International Sample of Monozygotic Twins Reared Apart." International Journal of Obesity, 1996; 20: 501-506.

Allison, DB, KR Fontaine, JE Manson, J Stevens, and TB VanItallie. "Annual Deaths Attributable to Obesity in the United States." Journal of the American Medical Association, 282: 1530-1538, 1999.

Allison, PD. Event History Analysis: Regression for Longitudinal Event Data. Beverly Hills, CA: Sage Publications, 1984.

Angrist, J. D. "Estimation of Limited-Dependent Variable Models With Dummy Endogenous Regressors: Simple Strategies for Empirical Practice." Journal of Business and Economic Statistics, 2001; 19, 2-17.

Associated Press. "U. S. Warning of Death Toll From Obesity." New York Times, December 14, 2001.

Becker, GS. "A Theory of the Allocation of Time." Economic Journal, 75: 493-517, 1965.

Brooks, A. "Teenage Girls Start Smoking to Lose Weight.” British Medical Journal (International), 317: 366, August 8, 1998.

Camp, DE, RC Klesges, and G Relyea. "The Relationship Between Body Weight Concerns and Adolescent Smoking." Health Psychology, 12: 24-32, 1993.

Centers for Disease Control and Prevention. "Cigarette Smoking-Attributable Mortality and Years of Potential Life Lost—United States 1990”. MMWR 42: 645-49, 1993.

Charlton, A. "Smoking and Weight Control in Teenagers." Public Health London, 98: 277-281, 1984.

Colditz GA, MR Segal, AH Myers, MJ Stampfer, W Willett, and FE Speizer. "Weight Change in Relation to Smoking Cessation Among Women." Journal of Smoking Related Diseases, 3: 145-153, 1992.

Crawley, HF and D While. "The Diet and Body Weight of British Teenage Smokers at 16-17 Years.” European Journal of Clinical Nutrition, 49: 904-914, 1995.

DeCicca, P, D Kenkel, and A Mathios. "Putting Out the Fires: Will Higher Taxes Reduce Youth Smoking?” Journal of Political Economy, 110: 144-169, 2002.

Douglas, SM and G Hariharan. "The Hazard of Starting Smoking: Estimates from a Split Sample Duration Model." Journal of Health Economics 13: 213-230, 1994.

Douglas, SM. “The Duration of the Smoking Habit.”Economic Inquiry, v XXXVI: 49-64, 1998.

Durbin, J. "Errors in Variables." Review of the International Statistical Institute, Vol. 22, pp. 23-32, 1954. 
Fehily AM, KM Phillips, and WG Yarnell. "Diet, Smoking, Social Class and Body Mass Index in the Caerphilly Heart Disease Study." American Journal of Clinical Nutrition, 40:827833, 1984.

Forster, M and AM Jones. "The Role of Tobacco Taxes in Starting and Quitting Smoking: Duration Analysis of British Data.” Working Paper, University of York, September 3, 1999.

French, SA, CL Perry, GR Leon and JA Fulkerson. "Weight Concerns, Dieting Behavior and Smoking Initiation in Adolescents: A Prospective Epidemiologic Study." American Journal of Public Health, 84: 1818-1820, 1994.

Gordon T, WB Kannel, TR Dawber, and D McGee. "Changes Associated with Quitting Cigarette Smoking: The Framingham Study." American Heart Journal, 90: 322-328, 1975.

Grossman, M. The Demand for Health: A Theoretical and Empirical Investigation. New York: Columbia University Press for the National Bureau of Economic Research, 1972.

Hausman J. "Specification Tests in Econometrics." Econometrica, 46: 1251-1271, 1978.

Heckman, J. J. and MaCurdy, T.E. "A Simultaneous Equations Linear Probability Model." Canadian Journal of Economics, February 1985, 28-37.

Huber, PJ. "The Behavior of Maximum Likelihood Estimates under Nonstandard Conditions." In Fifth Berkeley Symposium on Mathematical Statistics and Probability. Berkeley, California: University of California Press, 1967, 221-233.

Klesges, RC, VE Elliott, and LA Robinson. "Chronic Dieting and the Belief that Smoking Controls Body Weight in a Biracial, Population-Based Adolescent Sample." Tobacco Control, 6: 89-94, 1997.

Klesges, RC, A Myers, LM Klesges, and ME LaVasque. "Smoking, Body Weight and Their Effects on Smoking Behavior: A Comprehensive Review of the Literature."

Psychological Bulletin, 106: 204-230, 1989.

Klesges, RC, LA Robinson, and S Zbikowski. "Is Smoking Associated with Lower Body Mass Index in Adolescents? A Large-Scale Biracial Investigation." Addictive Behaviors, 23: 109-113, 1998.

Klesges RC, SM Zbikowski, HA Lando, CK Haddock, GW Talcott, and LA Robinson. "The Relationship Between Smoking and Body Weight in a Population of Young Military Personnel." Health Psychology, 17: 454-458, 1998.

Larkin FA, PP Basiotis, HA Riddick, KE Sykes, and EM Pao, "Dietary Patterns of Women Smokers and Non Smokers.” Journal of the American Dietetic Association, 90: 230-237, 1990.

Lissner, L, C Bengtsson, L Lapidus, and C Björkelund. "Smoking Initiation and Cessation in Relation to Body Fat Distribution Based on Data From a Study of Swedish Women." American Journal of Public Health, 82: 273-275, 1992. 
Maes, Hermine H. M., Michael C. Neale, and Lindon J. Eaves. "Genetic and Environmental Factors in Relative Body Weight and Human Adiposity" Behavior Genetics, 27, 4 (1997): 325-351.

Nemery B, NE Moavero, L Brasseur, and DC Stanescu. "Smoking, Lung Function and Body Weight.” British Medical Journal (Clinical Research Edition), 286: 249-251, 1983.

Pinkowish, MD. "Hand in Glove: Smoking Cessation \& Weight Gain.” Patient Care, 33: 134, 1999.

Tauras, JA, PM O’Malley, and LD Johnston. "Effects of Price and Access Laws on Teenage Smoking Initiation: A National Longitudinal Analysis.” NBER Working Paper, No. 8331, June 2001.

Tomeo CA, AE Field, CS Berkey, GA Colditz, and AL Frazier. "Weight Concerns, Weight Control Behaviors, and Smoking Initiation." Pediatrics. 104: 918-24, 1999.

Townsend J, H Wilkes, A Haines, and M Jarvis. "Adolescent Smokers Seen in General Practice: Health Lifestyle, Physical Measurements and Response to Antismoking Advise." British Medical Journal, 303: 947-950, 1991.

Tucker LA. "Cigarette Smoking Intentions and Obesity Among High School Males." Psychological Reports_52: 530, 1983.

U.S. Department of Health and Human Services. Preventing Tobacco Use Among Young People: A Report of the Surgeon General. Atlanta, Georgia: U.S. Department of Health and Human Services, Public Health Service, Centers for Disease Control and Prevention, National Center for Chronic Disease Prevention and Health Promotion, Office on Smoking and Health, 1994.

U.S. Department of Health and Human Services. The Health Benefits of Smoking Cessation: A Report of the Surgeon General, 1990. Atlanta Georgia: U.S. Dept. of Health and Human Services, Public Health Service, Centers for Disease Control, Center for Chronic Disease Prevention and Health Promotion, Office on Smoking and Health, 1990.

U.S. Department of Health and Human Services. The Pharmacology of Tobacco Use: Nicotine Addiction: A Report of the Surgeon General Atlanta, Georgia: U.S. Department of Health and Human Services, Public Health Service, Centers for Disease Control and Prevention, National Center for Chronic Disease Prevention and Health Promotion, Office on Smoking and Health, 1988.

Voorhees, CC, GB Schreiber, BC Schumann, F Biro, and PB Crawford. "Early Predictors of Daily Smoking in Young Women: The National Heart, Lung, and Blood Institute Growth and Health Study." 34: 616-624, 2002.

Wiseman, CV, RM Turco, SR Sunday, and KA Halmi. "Smoking and Body Image Concerns in Adolescent Girls.” International Journal of Eating Disorders, 24: 429-433, 1998.

Wu, D. "Alternative Tests of Independence Between Stochastic Regressors and Disturbances." Econometrica, Vol. 41, No. 4, pp. 733-750, 1973. 
Sample Means and Standard Deviations

\begin{tabular}{|c|c|c|c|c|}
\hline & \multicolumn{2}{|c|}{ Males } & \multicolumn{2}{|c|}{ Females } \\
\hline & Mean & $\begin{array}{c}\text { Standard } \\
\text { Deviation }\end{array}$ & Mean & $\begin{array}{c}\text { Standard } \\
\text { Deviation }\end{array}$ \\
\hline Initiated Smoking & 0.103 & 0.305 & 0.085 & 0.280 \\
\hline Initiated Heavy Smoking & 0.039 & 0.194 & 0.025 & 0.156 \\
\hline $\mathrm{BMI} \geq 85$ th Percentile & 0.321 & 0.467 & 0.246 & 0.431 \\
\hline Lose Weight & 0.245 & 0.430 & 0.451 & 0.498 \\
\hline Self Reported Underweight & 0.178 & 0.382 & 0.117 & 0.321 \\
\hline Self Reported Overweight & 0.205 & 0.404 & 0.319 & 0.466 \\
\hline Age & 16.570 & 1.616 & 16.639 & 1.630 \\
\hline Work & 0.499 & 0.500 & 0.505 & 0.500 \\
\hline African American & 0.278 & 0.448 & 0.317 & 0.466 \\
\hline Hispanic & 0.203 & 0.402 & 0.222 & 0.415 \\
\hline Dropout & 0.057 & 0.232 & 0.051 & 0.221 \\
\hline High School Degree & 0.063 & 0.244 & 0.068 & 0.252 \\
\hline In College & 0.117 & 0.322 & 0.156 & 0.363 \\
\hline Not Single & 0.005 & 0.074 & 0.012 & 0.110 \\
\hline Real Youth Income & 971.644 & 2028.962 & 795.134 & 1634.650 \\
\hline Household Size & 4.396 & 1.530 & 4.434 & 1.629 \\
\hline Living with Stepparent & 0.117 & 0.321 & 0.114 & 0.318 \\
\hline Living with One Parent & 0.265 & 0.442 & 0.284 & 0.451 \\
\hline Living with No Parent & 0.074 & 0.262 & 0.093 & 0.290 \\
\hline No Religion & 0.112 & 0.315 & 0.076 & 0.264 \\
\hline 1999 & 0.331 & 0.471 & 0.329 & 0.470 \\
\hline 2000 & 0.289 & 0.453 & 0.300 & 0.458 \\
\hline Real Cigarette Price & 1.666 & 0.305 & 1.660 & 0.302 \\
\hline Tobacco Producing State & 0.140 & 0.347 & 0.153 & 0.360 \\
\hline Depressed & 0.424 & 0.580 & 0.483 & 0.613 \\
\hline Behavior Problem & 1.827 & 1.454 & 1.764 & 1.443 \\
\hline Obese Mother & 0.258 & 0.438 & 0.258 & 0.438 \\
\hline
\end{tabular}

Sample size for males and females are 6,255 and 6,027 respectively. Blacks and Hispanics are oversampled in the NLYS97. Weighted means are similar for all variables except for the proportion of blacks and Hispanics. 


\section{Table 2}

\section{Smoking Initiation Equations: BMI $\geq 85$ th Percentile}

\begin{tabular}{|c|c|c|c|c|c|c|}
\hline \multirow[b]{2}{*}{ Independent Variables } & \multicolumn{3}{|c|}{$\begin{array}{c}\text { Smoking Initiation } \\
\text { Less Stringent (Any Quantity) }\end{array}$} & \multicolumn{3}{|c|}{$\begin{array}{c}\text { Smoking Initiation } \\
\text { More Stringent (15+ days) }\end{array}$} \\
\hline & $\begin{array}{c}\text { Both } \\
\text { Genders }\end{array}$ & Males & Females & $\begin{array}{c}\text { Both } \\
\text { Genders }\end{array}$ & Males & Females \\
\hline $\mathrm{BMI} \geq 85^{\text {th }}$ Percentile & $\begin{array}{c}0.042 \\
(1.20)\end{array}$ & $\begin{array}{r}0.018 \\
(0.38)\end{array}$ & $\begin{array}{r}0.105 \\
(1.93)\end{array}$ & $\begin{array}{c}0.020 \\
(0.39)\end{array}$ & $\begin{array}{l}-0.040 \\
(-0.60)\end{array}$ & $\begin{array}{c}0.166 \\
(1.99)\end{array}$ \\
\hline Real Cigarette Price & $\begin{array}{l}-0.158 \\
(-1.68)\end{array}$ & $\begin{array}{l}-0.312 \\
(-2.45)\end{array}$ & $\begin{array}{r}0.001 \\
(0.01)\end{array}$ & $\begin{array}{l}-0.165 \\
(-1.17)\end{array}$ & $\begin{array}{l}-0.422 \\
(-2.32)\end{array}$ & $\begin{array}{c}0.194 \\
(0.87)\end{array}$ \\
\hline Female & $\begin{array}{l}-0.095 \\
(-2.94)\end{array}$ & & & $\begin{array}{r}-0.220 \\
(-4.44)\end{array}$ & & \\
\hline Age & $\begin{array}{r}0.016 \\
(1.09)\end{array}$ & $\begin{array}{r}0.034 \\
(1.68)\end{array}$ & $\begin{array}{l}-0.006 \\
(-0.28)\end{array}$ & $\begin{array}{r}0.053 \\
(2.44)\end{array}$ & $\begin{array}{r}0.047 \\
(1.69)\end{array}$ & $\begin{array}{c}0.068 \\
(1.88)\end{array}$ \\
\hline Work & $\begin{array}{l}-0.041 \\
(-1.15)\end{array}$ & $\begin{array}{r}-0.017 \\
(-0.35)\end{array}$ & $\begin{array}{r}-0.059 \\
(-1.12)\end{array}$ & $\begin{array}{r}-0.021 \\
(-0.39)\end{array}$ & $\begin{array}{l}0.009 \\
(0.13)\end{array}$ & $\begin{array}{l}-0.063 \\
(-0.74)\end{array}$ \\
\hline African American & $\begin{array}{l}-0.296 \\
(-6.99)\end{array}$ & $\begin{array}{r}-0.149 \\
(-2.59)\end{array}$ & $\begin{array}{r}-0.474 \\
(-7.53)\end{array}$ & $\begin{array}{l}-0.352 \\
(-5.47)\end{array}$ & $\begin{array}{r}-0.199 \\
(-2.40)\end{array}$ & $\begin{array}{r}-0.623 \\
(-6.03)\end{array}$ \\
\hline Hispanic & $\begin{array}{l}-0.087 \\
(-1.99)\end{array}$ & $\begin{array}{r}0.028 \\
(0.48)\end{array}$ & $\begin{array}{l}-0.229 \\
(-3.47)\end{array}$ & $\begin{array}{l}-0.170 \\
(-2.46)\end{array}$ & $\begin{array}{l}-0.046 \\
(-0.54)\end{array}$ & $\begin{array}{r}-0.364 \\
(-3.03)\end{array}$ \\
\hline Dropout & $\begin{array}{r}0.349 \\
(5.34)\end{array}$ & $\begin{array}{r}0.370 \\
(4.27)\end{array}$ & $\begin{array}{r}0.313 \\
(3.14)\end{array}$ & $\begin{array}{r}0.414 \\
(4.66)\end{array}$ & $\begin{array}{r}0.411 \\
(3.69)\end{array}$ & $\begin{array}{r}0.435 \\
(2.95)\end{array}$ \\
\hline High School Degree & $\begin{array}{r}0.059 \\
(0.80)\end{array}$ & $\begin{array}{r}0.060 \\
(0.60)\end{array}$ & $\begin{array}{l}0.080 \\
(0.72)\end{array}$ & $\begin{array}{r}-0.003 \\
(-0.02)\end{array}$ & $\begin{array}{l}0.056 \\
(0.41)\end{array}$ & $\begin{array}{r}-0.059 \\
(-0.35)\end{array}$ \\
\hline In College & $\begin{array}{l}-0.063 \\
(-1.01)\end{array}$ & $\begin{array}{r}-0.099 \\
(-1.14)\end{array}$ & $\begin{array}{l}-0.004 \\
(-0.04)\end{array}$ & $\begin{array}{l}-0.162 \\
(-1.72)\end{array}$ & $\begin{array}{l}-0.144 \\
(-1.13)\end{array}$ & $\begin{array}{l}-0.193 \\
(-1.34)\end{array}$ \\
\hline Not Single & $\begin{array}{l}-0.219 \\
(-1.23)\end{array}$ & $\begin{array}{l}-0.398 \\
(-1.22)\end{array}$ & $\begin{array}{l}-0.136 \\
(-0.62)\end{array}$ & $\begin{array}{l}-0.651 \\
(-2.14)\end{array}$ & $\begin{array}{l}-0.593 \\
(-1.32)\end{array}$ & $\begin{array}{c}-0.732 \\
(-1.77)\end{array}$ \\
\hline Real Youth Income & $\begin{array}{l}0.00001 \\
(1.26)\end{array}$ & $\begin{array}{l}0.00002 \\
(1.48)\end{array}$ & $\begin{array}{l}-0.000005 \\
(-0.29)\end{array}$ & $\begin{array}{l}0.00002 \\
(1.82)\end{array}$ & $\begin{array}{l}0.00001 \\
(0.71)\end{array}$ & $\begin{array}{l}0.00004 \\
(2.12)\end{array}$ \\
\hline Household Size & $\begin{array}{c}-0.016 \\
(-1.47)\end{array}$ & $\begin{array}{r}0.002 \\
(0.11)\end{array}$ & $\begin{array}{l}-0.031 \\
(-1.96)\end{array}$ & $\begin{array}{r}-0.011 \\
(-0.68)\end{array}$ & $\begin{array}{c}0.032 \\
(1.60)\end{array}$ & $\begin{array}{c}-0.085 \\
(-2.59)\end{array}$ \\
\hline Living with Stepparent & $\begin{array}{c}0.135 \\
(2.64)\end{array}$ & $\begin{array}{c}0.073 \\
(1.05)\end{array}$ & $\begin{array}{c}0.188 \\
(2.49)\end{array}$ & $\begin{array}{c}0.202 \\
(2.63)\end{array}$ & $\begin{array}{c}0.157 \\
(1.62)\end{array}$ & $\begin{array}{r}0.245 \\
(1.94)\end{array}$ \\
\hline Living with One Parent & $\begin{array}{c}0.131 \\
(3.17)\end{array}$ & $\begin{array}{c}0.107 \\
(1.87)\end{array}$ & $\begin{array}{l}0.166 \\
(2.72)\end{array}$ & $\begin{array}{c}0.253 \\
(3.99)\end{array}$ & $\begin{array}{c}0.234 \\
(2.82)\end{array}$ & $\begin{array}{c}0.262 \\
(2.60)\end{array}$ \\
\hline Living with No Parent & $\begin{array}{c}0.212 \\
(3.24)\end{array}$ & $\begin{array}{c}0.177 \\
(1.95)\end{array}$ & $\begin{array}{r}0.273 \\
(2.88)\end{array}$ & $\begin{array}{r}0.441 \\
(4.88)\end{array}$ & $\begin{array}{c}0.462 \\
(3.95)\end{array}$ & $\begin{array}{c}0.380 \\
(2.63)\end{array}$ \\
\hline No Religion & $\begin{array}{r}0.022 \\
(0.40)\end{array}$ & $\begin{array}{r}-0.121 \\
(-1.66)\end{array}$ & $\begin{array}{c}0.204 \\
(2.51)\end{array}$ & $\begin{array}{c}0.123 \\
(1.64)\end{array}$ & $\begin{array}{c}0.058 \\
(0.63)\end{array}$ & $\begin{array}{c}0.239 \\
(1.93)\end{array}$ \\
\hline 1999 & $\begin{array}{r}0.020 \\
(0.38)\end{array}$ & $\begin{array}{r}0.075 \\
(1.08)\end{array}$ & $\begin{array}{c}-0.030 \\
(-0.39)\end{array}$ & $\begin{array}{c}-0.037 \\
(-0.48)\end{array}$ & $\begin{array}{c}0.041 \\
(0.41)\end{array}$ & $\begin{array}{r}-0.153 \\
(-1.25)\end{array}$ \\
\hline 2000 & $\begin{array}{l}-0.023 \\
(-0.34)\end{array}$ & $\begin{array}{c}0.082 \\
(0.89)\end{array}$ & $\begin{array}{r}-0.129 \\
(-1.23)\end{array}$ & $\begin{array}{r}-0.075 \\
(-0.72)\end{array}$ & $\begin{array}{c}0.098 \\
(0.76)\end{array}$ & $\begin{array}{r}-0.317 \\
(-1.85)\end{array}$ \\
\hline Tobacco Producing State & $\begin{array}{r}0.051 \\
(0.98)\end{array}$ & $\begin{array}{r}0.017 \\
(0.24)\end{array}$ & $\begin{array}{r}0.077 \\
(1.01)\end{array}$ & $\begin{array}{r}0.133 \\
(1.78)\end{array}$ & $\begin{array}{r}0.077 \\
(0.80)\end{array}$ & $\begin{array}{c}0.210 \\
(1.75)\end{array}$ \\
\hline Constant & $\begin{array}{l}-1.208 \\
(-4.51)\end{array}$ & $\begin{array}{l}-1.399 \\
(-3.86)\end{array}$ & $\begin{array}{l}-1.051 \\
(-2.64)\end{array}$ & $\begin{array}{l}-2.367 \\
(-6.02)\end{array}$ & $\begin{array}{l}-2.133 \\
(-4.27)\end{array}$ & $\begin{array}{l}-2.973 \\
(-4.60)\end{array}$ \\
\hline
\end{tabular}

Asymptotic z-statistics are in parentheses. The critical values for the z-statistic are $2.58(2.33), 1.96(1.64), 1.64(1.28)$ at the $1 \%, 5 \%$, and $10 \%$ significance levels, respectively, based on a two-tailed (one-tailed) test. Robust standard errors with additional correction for clustering at the person level are employed. Less stringent initiation sample size for males, females, and total are 6,255,6,027, and 12,282, respectively. More stringent initiation sample size for males, females, and total are 5,744,5,557, and 11,301, respectively. 


\section{Smoking Initiation Equations: Lose Weight}

\begin{tabular}{|c|c|c|c|c|c|c|}
\hline \multirow[b]{2}{*}{ Independent Variables } & \multicolumn{3}{|c|}{$\begin{array}{c}\text { Smoking Initiation } \\
\text { Less Stringent (Any Quantity) }\end{array}$} & \multicolumn{3}{|c|}{$\begin{array}{c}\text { Smoking Initiation } \\
\text { More Stringent }(15+\text { days }) \\
\end{array}$} \\
\hline & $\begin{array}{c}\text { Both } \\
\text { Genders }\end{array}$ & Males & Females & $\begin{array}{c}\text { Both } \\
\text { Genders }\end{array}$ & Males & Females \\
\hline Lose Weight & $\begin{array}{l}0.095 \\
(2.86)\end{array}$ & $\begin{array}{r}0.023 \\
(0.46)\end{array}$ & $\begin{array}{r}0.163 \\
(3.55)\end{array}$ & $\begin{array}{l}0.075 \\
(1.48)\end{array}$ & $\begin{array}{r}-0.009 \\
(-0.13)\end{array}$ & $\begin{array}{r}0.154 \\
(2.05)\end{array}$ \\
\hline Real Cigarette Price & $\begin{array}{l}-0.136 \\
(-1.47)\end{array}$ & $\begin{array}{l}-0.319 \\
(-2.51)\end{array}$ & $\begin{array}{r}0.043 \\
(0.32)\end{array}$ & $\begin{array}{l}-0.164 \\
(-1.17)\end{array}$ & $\begin{array}{r}-0.437 \\
(-2.41)\end{array}$ & $\begin{array}{r}0.193 \\
(0.89)\end{array}$ \\
\hline Female & $\begin{array}{l}-0.112 \\
(-3.46)\end{array}$ & & & $\begin{array}{l}-0.234 \\
(-4.78)\end{array}$ & & \\
\hline Age & $\begin{array}{r}0.021 \\
(1.45)\end{array}$ & $\begin{array}{c}0.036 \\
(1.81)\end{array}$ & $\begin{array}{c}0.0001 \\
(0.01)\end{array}$ & $\begin{array}{r}0.065 \\
(3.05)\end{array}$ & $\begin{array}{c}0.052 \\
(1.88)\end{array}$ & $\begin{array}{c}0.090 \\
(2.54)\end{array}$ \\
\hline Work & $\begin{array}{l}-0.026 \\
(-0.75)\end{array}$ & $\begin{array}{l}-0.004 \\
(-0.08)\end{array}$ & $\begin{array}{r}-0.047 \\
(-0.91)\end{array}$ & $\begin{array}{l}-0.012 \\
(-0.24)\end{array}$ & $\begin{array}{r}0.011 \\
(0.16)\end{array}$ & $\begin{array}{l}-0.048 \\
(-0.58)\end{array}$ \\
\hline African American & $\begin{array}{l}-0.278 \\
(-6.70)\end{array}$ & $\begin{array}{r}-0.133 \\
(-2.34)\end{array}$ & $\begin{array}{r}-0.437 \\
(-7.16)\end{array}$ & $\begin{array}{r}-0.350 \\
(-5.54)\end{array}$ & $\begin{array}{l}-0.188 \\
(-2.31)\end{array}$ & $\begin{array}{r}-0.601 \\
(-5.78)\end{array}$ \\
\hline Hispanic & $\begin{array}{l}-0.106 \\
(-2.49)\end{array}$ & $\begin{array}{r}0.018 \\
(0.31)\end{array}$ & $\begin{array}{l}-0.244 \\
(-3.86)\end{array}$ & $\begin{array}{l}-0.195 \\
(-2.86)\end{array}$ & $\begin{array}{l}-0.061 \\
(-0.72)\end{array}$ & $\begin{array}{l}-0.377 \\
(-3.26)\end{array}$ \\
\hline Dropout & $\begin{array}{r}0.356 \\
(5.68)\end{array}$ & $\begin{array}{c}0.384 \\
(4.53)\end{array}$ & $\begin{array}{r}0.322 \\
(3.41)\end{array}$ & $\begin{array}{r}0.423 \\
(4.96)\end{array}$ & $\begin{array}{r}0.430 \\
(3.96)\end{array}$ & $\begin{array}{r}0.449 \\
(3.23)\end{array}$ \\
\hline High School Degree & $\begin{array}{r}0.058 \\
(0.80)\end{array}$ & $\begin{array}{r}0.063 \\
(0.63)\end{array}$ & $\begin{array}{c}0.070 \\
(0.64)\end{array}$ & $\begin{array}{c}0.011 \\
(0.10)\end{array}$ & $\begin{array}{r}0.059 \\
(0.43)\end{array}$ & $\begin{array}{c}-0.023 \\
(-0.14)\end{array}$ \\
\hline In College & $\begin{array}{c}-0.070 \\
(-1.14)\end{array}$ & $\begin{array}{l}-0.105 \\
(-1.21)\end{array}$ & $\begin{array}{c}-0.010 \\
(-0.11)\end{array}$ & $\begin{array}{c}-0.180 \\
(-1.95)\end{array}$ & $\begin{array}{l}-0.151 \\
(-1.19)\end{array}$ & $\begin{array}{l}-0.228 \\
(-1.65)\end{array}$ \\
\hline Not Single & $\begin{array}{c}-0.165 \\
(-0.96)\end{array}$ & $\begin{array}{l}-0.397 \\
(-1.22)\end{array}$ & $\begin{array}{c}-0.038 \\
(-0.18)\end{array}$ & $\begin{array}{l}-0.647 \\
(-2.14)\end{array}$ & $\begin{array}{l}-0.592 \\
(-1.32)\end{array}$ & $\begin{array}{l}-0.740 \\
(-1.82)\end{array}$ \\
\hline Real Youth Income & $\begin{array}{l}0.00001 \\
(1.13)\end{array}$ & $\begin{array}{l}0.00002 \\
(1.51)\end{array}$ & $\begin{array}{l}-0.00001 \\
(-0.47)\end{array}$ & $\begin{array}{l}0.00002 \\
(1.69)\end{array}$ & $\begin{array}{l}0.00001 \\
(0.74)\end{array}$ & $\begin{array}{l}0.00004 \\
(1.96)\end{array}$ \\
\hline Household Size & $\begin{array}{l}-0.014 \\
(-1.33)\end{array}$ & $\begin{array}{c}-0.003 \\
(-0.21)\end{array}$ & $\begin{array}{c}-0.020 \\
(-1.35)\end{array}$ & $\begin{array}{l}-0.012 \\
(-0.73)\end{array}$ & $\begin{array}{c}0.030 \\
(1.52)\end{array}$ & $\begin{array}{l}-0.079 \\
(-2.58)\end{array}$ \\
\hline Living with Stepparent & $\begin{array}{r}0.150 \\
(3.00)\end{array}$ & $\begin{array}{c}0.084 \\
(1.22)\end{array}$ & $\begin{array}{r}0.211 \\
(2.89)\end{array}$ & $\begin{array}{c}0.209 \\
(2.75)\end{array}$ & $\begin{array}{c}0.173 \\
(1.80)\end{array}$ & $\begin{array}{c}0.243 \\
(1.94)\end{array}$ \\
\hline Living with One Parent & $\begin{array}{c}0.123 \\
(3.04)\end{array}$ & $\begin{array}{c}0.108 \\
(1.91)\end{array}$ & $\begin{array}{c}0.149 \\
(2.53)\end{array}$ & $\begin{array}{c}0.272 \\
(4.40)\end{array}$ & $\begin{array}{c}0.241 \\
(2.96)\end{array}$ & $\begin{array}{r}0.305 \\
(3.14)\end{array}$ \\
\hline Living with No Parent & $\begin{array}{c}0.186 \\
(2.89)\end{array}$ & $\begin{array}{c}0.166 \\
(1.84)\end{array}$ & $\begin{array}{r}0.231 \\
(2.52)\end{array}$ & $\begin{array}{c}0.423 \\
(4.77)\end{array}$ & $\begin{array}{c}0.450 \\
(3.87)\end{array}$ & $\begin{array}{r}0.367 \\
(2.63)\end{array}$ \\
\hline No Religion & $\begin{array}{r}0.015 \\
(0.28)\end{array}$ & $\begin{array}{l}-0.115 \\
(-1.61)\end{array}$ & $\begin{array}{c}0.183 \\
(2.32)\end{array}$ & $\begin{array}{r}0.117 \\
(1.60)\end{array}$ & $\begin{array}{c}0.057 \\
(0.63)\end{array}$ & $\begin{array}{c}0.232 \\
(1.94)\end{array}$ \\
\hline 1999 & $\begin{array}{c}0.016 \\
(0.31)\end{array}$ & $\begin{array}{c}0.083 \\
(1.22)\end{array}$ & $\begin{array}{c}-0.046 \\
(-0.62)\end{array}$ & $\begin{array}{l}-0.038 \\
(-0.50)\end{array}$ & $\begin{array}{c}0.057 \\
(0.58)\end{array}$ & $\begin{array}{l}-0.170 \\
(-1.44)\end{array}$ \\
\hline 2000 & $\begin{array}{c}-0.044 \\
(-0.65)\end{array}$ & $\begin{array}{c}0.084 \\
(0.92)\end{array}$ & $\begin{array}{r}-0.167 \\
(-1.64)\end{array}$ & $\begin{array}{l}-0.088 \\
(-0.85)\end{array}$ & $\begin{array}{l}0.101 \\
(0.78)\end{array}$ & $\begin{array}{l}-0.330 \\
(-1.99)\end{array}$ \\
\hline Tobacco Producing State & $\begin{array}{r}0.042 \\
(0.83)\end{array}$ & $\begin{array}{c}-0.004 \\
(-0.06)\end{array}$ & $\begin{array}{r}0.074 \\
(1.00)\end{array}$ & $\begin{array}{c}0.122 \\
(1.65)\end{array}$ & $\begin{array}{c}0.064 \\
(0.66)\end{array}$ & $\begin{array}{c}0.180 \\
(1.53)\end{array}$ \\
\hline Constant & $\begin{array}{l}-1.346 \\
(-5.13)\end{array}$ & $\begin{array}{l}-1.425 \\
(-3.96)\end{array}$ & $\begin{array}{l}-1.311 \\
(-3.40)\end{array}$ & $\begin{array}{l}-2.578 \\
(-6.67)\end{array}$ & $\begin{array}{l}-2.198 \\
(-4.44)\end{array}$ & $\begin{array}{l}-3.384 \\
(-5.34)\end{array}$ \\
\hline
\end{tabular}

Asymptotic z-statistics are in parentheses. The critical values for the z-statistic are 2.58 (2.33), 1.96 (1.64), 1.64 (1.28) at the $1 \%, 5 \%$, and $10 \%$ significance levels, respectively, based on a two-tailed (one-tailed) test. Robust standard errors with additional correction for clustering at the person level are employed. Less stringent initiation sample size for males, females, and total are 6,426,6,385, and 12,811, respectively. More stringent initiation sample size for males, females, and total are 5,906, 5,882, and 11,788, respectively. 


\section{Table 4}

\section{Smoking Initiation Equations:}

Underweight, Overweight, Normal Weight (Benchmark)

\begin{tabular}{|c|c|c|c|c|c|c|}
\hline \multirow[b]{2}{*}{ Independent Variables } & \multicolumn{3}{|c|}{$\begin{array}{c}\text { Smoking Initiation } \\
\text { Less Stringent (Any Quantity) }\end{array}$} & \multicolumn{3}{|c|}{$\begin{array}{c}\text { Smoking Initiation } \\
\text { More Stringent (15+ days) }\end{array}$} \\
\hline & $\begin{array}{c}\text { Both } \\
\text { Genders }\end{array}$ & Males & Females & $\begin{array}{c}\text { Both } \\
\text { Genders }\end{array}$ & Males & Females \\
\hline Underweight & $\begin{array}{l}-0.120 \\
(-2.49)\end{array}$ & $\begin{array}{l}-0.155 \\
(-2.57)\end{array}$ & $\begin{array}{c}-0.062 \\
(-0.78)\end{array}$ & $\begin{array}{l}-0.097 \\
(-1.37)\end{array}$ & $\begin{array}{l}-0.013 \\
(-0.16)\end{array}$ & $\begin{array}{l}-0.371 \\
(-2.22)\end{array}$ \\
\hline Overweight & $\begin{array}{r}0.060 \\
(1.65)\end{array}$ & $\begin{array}{l}-0.033 \\
(-0.59)\end{array}$ & $\begin{array}{r}0.156 \\
(3.17)\end{array}$ & $\begin{array}{r}0.035 \\
(0.63)\end{array}$ & $\begin{array}{r}-0.042 \\
(-0.53)\end{array}$ & $\begin{array}{r}0.113 \\
(1.44)\end{array}$ \\
\hline Real Cigarette Price & $\begin{array}{l}-0.143 \\
(-1.54)\end{array}$ & $\begin{array}{l}-0.323 \\
(-2.54)\end{array}$ & $\begin{array}{r}0.041 \\
(0.30)\end{array}$ & $\begin{array}{l}-0.168 \\
(-1.21)\end{array}$ & $\begin{array}{l}-0.438 \\
(-2.42)\end{array}$ & $\begin{array}{l}0.209 \\
(0.96)\end{array}$ \\
\hline Female & $\begin{array}{l}-0.107 \\
(-3.36)\end{array}$ & & & $\begin{array}{l}-0.228 \\
(-4.76)\end{array}$ & & \\
\hline Age & $\begin{array}{r}0.019 \\
(1.30)\end{array}$ & $\begin{array}{r}0.035 \\
(1.75)\end{array}$ & $\begin{array}{l}-0.003 \\
(-0.14)\end{array}$ & $\begin{array}{r}0.064 \\
(3.00)\end{array}$ & $\begin{array}{r}0.051 \\
(1.86)\end{array}$ & $\begin{array}{l}0.086 \\
(2.46)\end{array}$ \\
\hline Work & $\begin{array}{l}-0.026 \\
(-0.74)\end{array}$ & $\begin{array}{l}-0.006 \\
(-0.12)\end{array}$ & $\begin{array}{r}-0.043 \\
(-0.84)\end{array}$ & $\begin{array}{l}-0.013 \\
(-0.25)\end{array}$ & $\begin{array}{l}0.010 \\
(0.15)\end{array}$ & $\begin{array}{l}-0.055 \\
(-0.66)\end{array}$ \\
\hline African American & $\begin{array}{l}-0.274 \\
(-6.60)\end{array}$ & $\begin{array}{l}-0.137 \\
(-2.39)\end{array}$ & $\begin{array}{l}-0.434 \\
(-7.12)\end{array}$ & $\begin{array}{l}-0.349 \\
(-5.51)\end{array}$ & $\begin{array}{l}-0.191 \\
(-2.32)\end{array}$ & $\begin{array}{l}-0.607 \\
(-5.85)\end{array}$ \\
\hline Hispanic & $\begin{array}{l}-0.101 \\
(-2.36)\end{array}$ & $\begin{array}{r}0.018 \\
(0.30)\end{array}$ & $\begin{array}{r}-0.239 \\
(-3.77)\end{array}$ & $\begin{array}{l}-0.193 \\
(-2.84)\end{array}$ & $\begin{array}{c}-0.062 \\
(-0.73)\end{array}$ & $\begin{array}{l}-0.387 \\
(-3.36)\end{array}$ \\
\hline Dropout & $\begin{array}{c}0.354 \\
(5.64)\end{array}$ & $\begin{array}{c}0.381 \\
(4.49)\end{array}$ & $\begin{array}{r}0.314 \\
(3.32)\end{array}$ & $\begin{array}{r}0.420 \\
(4.94)\end{array}$ & $\begin{array}{c}0.429 \\
(3.95)\end{array}$ & $\begin{array}{c}0.450 \\
(3.27)\end{array}$ \\
\hline High School Degree & $\begin{array}{r}0.061 \\
(0.83)\end{array}$ & $\begin{array}{c}0.063 \\
(0.63)\end{array}$ & $\begin{array}{r}0.077 \\
(0.70)\end{array}$ & $\begin{array}{c}0.012 \\
(0.12)\end{array}$ & $\begin{array}{c}0.056 \\
(0.41)\end{array}$ & $\begin{array}{l}-0.009 \\
(-0.05)\end{array}$ \\
\hline In College & $\begin{array}{c}-0.071 \\
(-1.16)\end{array}$ & $\begin{array}{l}-0.101 \\
(-1.17)\end{array}$ & $\begin{array}{c}-0.014 \\
(-0.16)\end{array}$ & $\begin{array}{c}-0.179 \\
(-1.93)\end{array}$ & $\begin{array}{c}-0.150 \\
(-1.18)\end{array}$ & $\begin{array}{l}-0.224 \\
(-1.62)\end{array}$ \\
\hline Not Single & $\begin{array}{r}-0.169 \\
(-0.98)\end{array}$ & $\begin{array}{l}-0.410 \\
(-1.26)\end{array}$ & $\begin{array}{c}-0.037 \\
(-0.18)\end{array}$ & $\begin{array}{c}-0.657 \\
(-2.18)\end{array}$ & $\begin{array}{c}-0.590 \\
(-1.31)\end{array}$ & $\begin{array}{l}-0.767 \\
(-1.88)\end{array}$ \\
\hline Real Youth Income & $\begin{array}{l}0.00001 \\
(1.18)\end{array}$ & $\begin{array}{l}0.00002 \\
(1.56)\end{array}$ & $\begin{array}{l}-0.00001 \\
(-0.43)\end{array}$ & $\begin{array}{l}0.00002 \\
(1.72)\end{array}$ & $\begin{array}{l}0.00001 \\
(0.75)\end{array}$ & $\begin{array}{l}0.00004 \\
(2.00)\end{array}$ \\
\hline Household Size & $\begin{array}{l}-0.014 \\
(-1.29)\end{array}$ & $\begin{array}{l}-0.004 \\
(-0.26)\end{array}$ & $\begin{array}{c}-0.018 \\
(-1.22)\end{array}$ & $\begin{array}{l}-0.012 \\
(-0.72)\end{array}$ & $\begin{array}{r}0.030 \\
(1.50)\end{array}$ & $\begin{array}{l}-0.077 \\
(-2.49)\end{array}$ \\
\hline Living with Stepparent & $\begin{array}{c}0.152 \\
(3.03)\end{array}$ & $\begin{array}{r}0.081 \\
(1.17)\end{array}$ & $\begin{array}{c}0.218 \\
(2.98)\end{array}$ & $\begin{array}{c}0.208 \\
(2.73)\end{array}$ & $\begin{array}{c}0.171 \\
(1.78)\end{array}$ & $\begin{array}{r}0.242 \\
(1.93)\end{array}$ \\
\hline Living with One Parent & $\begin{array}{l}0.123 \\
(3.04)\end{array}$ & $\begin{array}{c}0.107 \\
(1.90)\end{array}$ & $\begin{array}{c}0.150 \\
(2.54)\end{array}$ & $\begin{array}{c}0.271 \\
(4.39)\end{array}$ & $\begin{array}{c}0.241 \\
(2.95)\end{array}$ & $\begin{array}{c}0.298 \\
(3.08)\end{array}$ \\
\hline Living with No Parent & $\begin{array}{r}0.187 \\
(2.91)\end{array}$ & $\begin{array}{r}0.165 \\
(1.83)\end{array}$ & $\begin{array}{r}0.235 \\
(2.56)\end{array}$ & $\begin{array}{r}0.423 \\
(4.78)\end{array}$ & $\begin{array}{r}0.447 \\
(3.85)\end{array}$ & $\begin{array}{r}0.371 \\
(2.65)\end{array}$ \\
\hline No Religion & $\begin{array}{c}0.013 \\
(0.24)\end{array}$ & $\begin{array}{c}-0.114 \\
(-1.59)\end{array}$ & $\begin{array}{c}0.176 \\
(2.22)\end{array}$ & $\begin{array}{c}0.113 \\
(1.55)\end{array}$ & $\begin{array}{c}0.059 \\
(0.65)\end{array}$ & $\begin{array}{c}0.220 \\
(1.84)\end{array}$ \\
\hline 1999 & $\begin{array}{c}0.016 \\
(0.31)\end{array}$ & $\begin{array}{c}0.079 \\
(1.15)\end{array}$ & $\begin{array}{c}-0.046 \\
(-0.62)\end{array}$ & $\begin{array}{c}-0.039 \\
(-0.52)\end{array}$ & $\begin{array}{c}0.057 \\
(0.57)\end{array}$ & $\begin{array}{l}-0.184 \\
(-1.55)\end{array}$ \\
\hline 2000 & $\begin{array}{r}-0.041 \\
(-0.60)\end{array}$ & $\begin{array}{r}0.085 \\
(0.93)\end{array}$ & $\begin{array}{l}-0.165 \\
(-1.62)\end{array}$ & $\begin{array}{l}-0.086 \\
(-0.83)\end{array}$ & $\begin{array}{r}0.101 \\
(0.79)\end{array}$ & $\begin{array}{l}-0.348 \\
(-2.08)\end{array}$ \\
\hline Tobacco Producing State & $\begin{array}{r}0.043 \\
(0.83)\end{array}$ & $\begin{array}{l}-0.009 \\
(-0.13)\end{array}$ & $\begin{array}{r}0.089 \\
(1.21)\end{array}$ & $\begin{array}{r}0.120 \\
(1.64)\end{array}$ & $\begin{array}{c}0.063 \\
(0.66)\end{array}$ & $\begin{array}{c}0.188 \\
(1.60)\end{array}$ \\
\hline Constant & $\begin{array}{l}-1.275 \\
(-4.86)\end{array}$ & $\begin{array}{r}-1.355 \\
(-3.77) \\
\end{array}$ & $\begin{array}{r}-1.243 \\
(-3.22)\end{array}$ & $\begin{array}{r}-2.521 \\
(-6.57) \\
\end{array}$ & $\begin{array}{r}-2.177 \\
(-4.43) \\
\end{array}$ & $\begin{array}{r}-3.281 \\
(-5.21) \\
\end{array}$ \\
\hline
\end{tabular}


Table 5

Predicted Probabilities and Cigarette Price Elasticities - Males

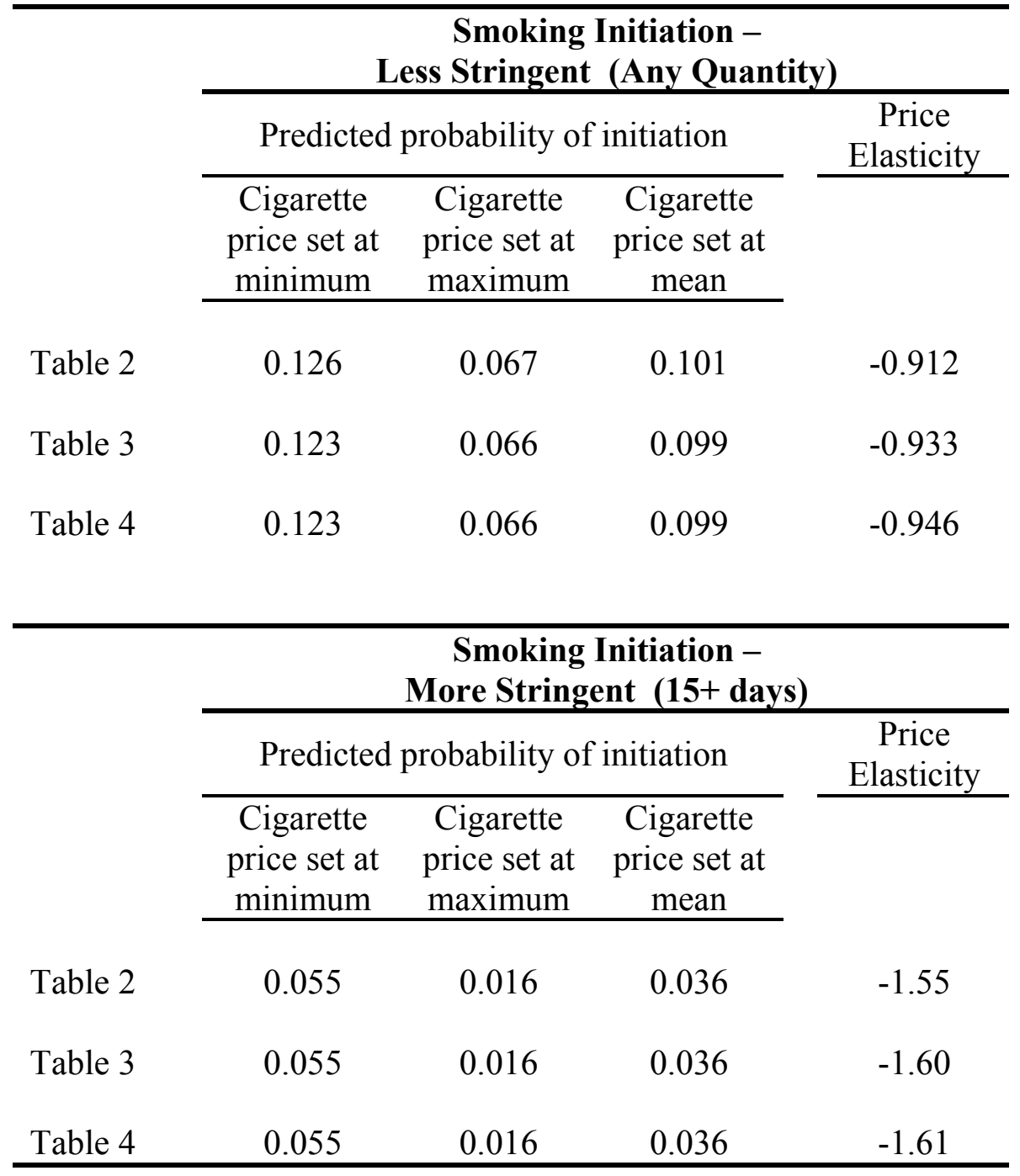


Table 6

Predicted Probabilities - Females

\begin{tabular}{|c|c|c|c|c|}
\hline \multirow[b]{3}{*}{ Table 2} & \multicolumn{4}{|c|}{$\begin{array}{c}\text { Smoking Initiation } \\
\text { Less Stringent (Any Quantity) }\end{array}$} \\
\hline & $\begin{array}{l}\text { Minimum } \\
\text { (Discrete 0) }\end{array}$ & $\begin{array}{l}\text { Maximum } \\
\text { (Discrete 1) }\end{array}$ & $\begin{array}{l}\text { Difference } \\
\text { max.-min. }\end{array}$ & $\begin{array}{l}\text { Percent } \\
\text { increase }\end{array}$ \\
\hline & \multirow{3}{*}{0.076} & \multirow{3}{*}{0.092} & \multirow{3}{*}{0.016} & \multirow{3}{*}{$21.1 \%$} \\
\hline $\mathrm{BMI} \geq 85$ th Percentile & & & & \\
\hline Table 3 & & & & \\
\hline Lose Weight & \multirow[t]{2}{*}{0.069} & \multirow[t]{2}{*}{0.094} & \multirow[t]{2}{*}{0.025} & \multirow[t]{2}{*}{$36.2 \%$} \\
\hline$\underline{\text { Table } 4}$ & & & & \\
\hline \multirow[t]{3}{*}{ Self Reported Overweight } & 0.072 & 0.096 & 0.024 & $33.3 \%$ \\
\hline & \multicolumn{4}{|c|}{$\begin{array}{l}\text { Smoking Initiation } \\
\text { More Stringent }(15+\text { days })\end{array}$} \\
\hline & $\begin{array}{l}\text { Minimum } \\
\text { (Discrete 0) }\end{array}$ & $\begin{array}{l}\text { Maximum } \\
\text { (Discrete 1) }\end{array}$ & $\begin{array}{l}\text { Difference } \\
\text { max.-min. }\end{array}$ & $\begin{array}{l}\text { Percent } \\
\text { increase }\end{array}$ \\
\hline \multicolumn{5}{|l|}{$\underline{\text { Table } 2}$} \\
\hline $\mathrm{BMI} \geq 85^{\text {th }}$ Percentile & 0.016 & 0.023 & 0.007 & $43.8 \%$ \\
\hline \multicolumn{5}{|l|}{$\underline{\text { Table } 3}$} \\
\hline Lose Weight & 0.014 & 0.021 & 0.007 & $50.0 \%$ \\
\hline \multicolumn{5}{|l|}{$\underline{\text { Table } 4}$} \\
\hline Self Reported Overweight & 0.015 & 0.020 & 0.005 & $33.3 \%$ \\
\hline
\end{tabular}


Table 7

Comparing OLS results with Instrumental Variable Results

\begin{tabular}{lcccc}
\hline & \multicolumn{2}{c}{$\begin{array}{c}\text { Smoking Initiation - } \\
\text { Less Stringent }\end{array}$} & \multicolumn{2}{c}{$\begin{array}{c}\text { Smoking Initiation - } \\
\text { More Stringent }\end{array}$} \\
\cline { 2 - 5 } BMI $\geq 85^{\text {th }}$ Percentile days)
\end{tabular}

Asymptotic t-ratios are in parentheses. The critical values for the t-ratios are $2.58(2.33), 1.96(1.64), 1.64$ (1.28) at the $1 \%, 5 \%$, and $10 \%$ significance levels, respectively, based on a two-tailed (one-tailed) test. Robust standard errors with additional correction for clustering at the person level are employed. Less stringent and more stringent initiation sample sizes are 4,743 and 4,383, respectively. All models also include age, work status, race, education status, youth income, household size, living arrangements, religion, and year indicators. 
Table 8

Subjective Weight Results for Females when Depression and Behavior are Held Constant

\begin{tabular}{|c|c|c|c|c|}
\hline & $\begin{array}{r}\text { Smoking } \\
\text { Less Stringen } \\
\end{array}$ & $\begin{array}{l}\text { tiation - } \\
\text { ny Quantity) }\end{array}$ & $\begin{array}{r}\text { Smokin } \\
\text { More Strin } \\
\end{array}$ & $\begin{array}{l}\text { tiation - } \\
(15+\text { days }) \\
\end{array}$ \\
\hline & $\begin{array}{c}\text { Depression } \\
\text { Excluded }\end{array}$ & $\begin{array}{c}\text { Depression } \\
\text { Included }\end{array}$ & $\begin{array}{c}\text { Depression } \\
\text { Excluded }\end{array}$ & $\begin{array}{c}\text { Depression } \\
\text { Included }\end{array}$ \\
\hline Panel A & & & & \\
\hline Lose Weight & $\begin{array}{l}0.143 \\
(2.60)\end{array}$ & $\begin{array}{l}0.137 \\
(2.47)\end{array}$ & $\begin{array}{l}0.085 \\
(0.91)\end{array}$ & $\begin{array}{l}0.077 \\
(0.82)\end{array}$ \\
\hline Depression & - & $\begin{array}{l}0.078 \\
(1.76)\end{array}$ & - & $\begin{array}{l}0.065 \\
(0.85)\end{array}$ \\
\hline$\underline{\text { Panel B }}$ & & & & \\
\hline Self Overweight & $\begin{array}{l}0.134 \\
(2.24)\end{array}$ & $\begin{array}{l}0.127 \\
(2.12)\end{array}$ & $\begin{array}{l}0.101 \\
(1.01)\end{array}$ & $\begin{array}{l}0.096 \\
(0.95)\end{array}$ \\
\hline Depression & & $\begin{array}{l}0.081 \\
(1.84) \\
\end{array}$ & & $\begin{array}{l}0.075 \\
(0.98) \\
\end{array}$ \\
\hline & $\begin{array}{l}\text { Behavior } \\
\text { Excluded }\end{array}$ & $\begin{array}{l}\text { Behavior } \\
\text { Included }\end{array}$ & $\begin{array}{l}\text { Behavior } \\
\text { Excluded }\end{array}$ & $\begin{array}{l}\text { Behavior } \\
\text { Included }\end{array}$ \\
\hline Panel C & & & & \\
\hline$\overline{\text { Lose Weight }}$ & $\begin{array}{l}0.143 \\
(2.60)\end{array}$ & $\begin{array}{l}0.129 \\
(2.31)\end{array}$ & $\begin{array}{l}0.085 \\
(0.91)\end{array}$ & $\begin{array}{l}0.067 \\
(0.70)\end{array}$ \\
\hline Behavior & & $\begin{array}{l}0.062 \\
(3.33)\end{array}$ & & $\begin{array}{l}0.072 \\
(2.39)\end{array}$ \\
\hline$\underline{\text { Panel D }}$ & & & & \\
\hline Self Overweight & $\begin{array}{l}0.134 \\
(2.24)\end{array}$ & $\begin{array}{l}0.115 \\
(1.91)\end{array}$ & $\begin{array}{l}0.101 \\
(1.01)\end{array}$ & $\begin{array}{l}0.084 \\
(0.82)\end{array}$ \\
\hline Behavior & & $\begin{array}{l}0.063 \\
(3.42) \\
\end{array}$ & & $\begin{array}{l}0.077 \\
(2.56) \\
\end{array}$ \\
\hline $\begin{array}{l}\text { Asymptotic } \mathrm{z} \text {-statistic } \\
1.64(1.28) \text { at the } 1 \% \text {, } \\
\text { Robust standard error } \\
\text { stringent (more string } \\
\text { (4013), and } 4347 \text { ( } 40 \\
\text { income, household si }\end{array}$ & $\begin{array}{l}\mathrm{n} \text { parentheses. } \\
\text { nd } 10 \% \text { signific } \\
\text { additional corre } \\
\text { itiation sample s } \\
\text { spectively. All } \mathrm{m} \\
\text { ng arrangements }\end{array}$ & $\begin{array}{l}\text { itical values for } \\
\text { evels, respective } \\
\text { for clustering at } \\
\text { r Panel A, B, C, } \\
\text { also include ag } \\
\text { gion, and year in }\end{array}$ & $\begin{array}{l}\text {-statistic are } 2.5 \\
\text { ased on a two-t } \\
\text { erson level are } \\
\text { D are } 4353 \text { ( } 40 \\
\text { rk status, race, } \\
\text { ors. }\end{array}$ & $\begin{array}{l}\text { 33), } 1.96(1.64), \\
\text { (one-tailed) test. } \\
\text { oyed. Less } \\
347 \text { (4010), } 4352 \\
\text { tion status, youth }\end{array}$ \\
\hline
\end{tabular}

